\title{
EFFECT OF WATER REGIMES ON YIELD AND QUALITY OF APPLE UNDER SEMI-ARID, LIBYA
}

\author{
Ahmed M. Hassan*
}

\begin{abstract}
This study, was carried out in 2011/2012, to investigate the yield and quality parameters of apple fruits (double red delicious) with different irrigation systems; surface and trickle irrigation and with different water levels; 100, 75 and $50 \%$ of $E T_{c}$. Traditional irrigation (rainfall irrigation) presented $34.8 \%$ from $E T_{c}$. The water irrigation requirement was determined by using Penman-Monteith's equation. An increase in fruit yield, properties and quality (fruit diameter, fruit weight, total soluble solid and sugar) has been noted with trickle irrigation method comparing with surface and rainfall irrigations. The highest fruit diameter $(80.9 \mathrm{~mm})$, fruit mass $(216.3 \mathrm{~g})$, extra and class 1 fruit ratios (36.2 and 36.5\%), total soluble solid (1.551 ton/fed) and sugar (1.38 ton/fed) were observed with DET 100 treatment. To obtain a high quantity and quality apples, DET 100 treatment with $100 \%$ ETc and trickle irrigation system are recommended during transition from rainfall and surface irrigation to trickle irrigation for similar climatic and soil conditions. The results showed that trickle irrigation system increases the qualitative and quantitative properties of apple fruits.
\end{abstract}

Key words: surface irrigation, trickle irrigation, deficit irrigation, apple, yield, water use efficiency, quality parameters.

\section{INTRODUCTION}

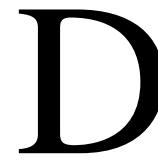
eficit irrigation is a strategy which allows a crop to sustain some degree of water deficit in order to reduce irrigation costs and potentially increase revenues. English and Raja (1996) described three deficit irrigation case studies in which the reductions in irrigation costs were greater than the reductions in revenue due to reduced yields. Deficit irrigation can lead, in principle, to increased profits where water costs are high or where water supplies are limited.

\footnotetext{
* Assis. Prof., Ag. Eng. Dept., Faculty of Ag., Cairo Univ.
} 
In these case studies, crop value was associated closely with yield, and crop grade and marketability were not germane. Under these circumstances, deficit irrigation can be a practical choice for growers. In general, deficit trickle irrigation was shown to initially increase yield as a result of induction of stress and the production of a higher number of fruits (Fallahi et al., 2010).

Deficit irrigation may have a positive impact on environmental quality. Dabbou et al (2010) studied the effect of three irrigation regimes on the fruit and quality of oil olive. The results showed that irrigation positively affected both fruit and oil quality. Shock et al. (1992) stated that potatoes can tolerate limited deficit irrigation before tuber set without significant reductions in external and internal tuber quality. UNECE Standard (2007 and 2011) stated that the quality parameters of apple fruits take into consideration fruit diameter, weight, fruit size classification, content of soluble solids (TSS), firmness, starch conversion, streif Index, background colour, polyphenols and anthocyanins content. Firmness is an important quality especially for shipment to distant markets. Caspari et al (1996) found no change in firmness of Asian pear grown under water deficit. In apple, fruit from plants grown under water deficit conditions were firmer as observed by Kilili et al. (1996). The total soluble content includes sugars, organic acids, sorbitol, some inorganic substances and vitamins which are important indicators of the maturity level (Maja, et al., 2009). Numerous authors have reported an increase in TSS under plant deficit (Kilili et al., 1996 and Mills et al., 1996). In Alagoas (Brazil), the drought period determines the sugar apple production period, so the use of irrigation is essential as a way of staggering production over the year (Endres, 2007). Maria et al. (2006) evaluated the influence of seven different levels of irrigation applied to trees grown in a super high density orchard in the Sacramento Valley of California. The results showed that the total polyphenol levels and oxidative stability decreased as the trees received more water.

The objectives of this research were: (i) to determine apple fruit yield response to different water regimes by full and partial $E T_{c}$ replacement; (ii) to compare the responses of several quality parameters to different 
water regimes under surface and trickle irrigation systems and; (iii) to evaluate the potential for surface and trickle irrigation to improve the apple production and quality.

\section{MATERIALS AND METHODS}

\section{Experimental conditions}

The study was conducted at Elbayda (البيضاء), Libya. Experiment was done during the 2011/2012 growing season in a commercial apple (double red delicious) orchard (spacing $5 \times 5$ m) in Raas-Eltorab (رأس تراب (latitude $32^{\circ} 44^{\prime} \mathrm{N}$, longitude $21^{\circ} 53^{\prime} \mathrm{E}$ ). The elevation of region is $649 \mathrm{~m}$ high, with average temperatures that ranged between 9.5 and 23.6 ${ }^{\circ} \mathrm{C}$, rainfall of $549.1 \mathrm{~mm}$, and relative humidity ranged between 59 to $79.3 \%$ (table 1) according to Libyan Meteorological Department, Tripoli.

\section{Table (1): Monthly climatic data (1946-2011) of the experimental} area.

\section{Climatic parameters}

\begin{tabular}{|c|c|c|c|c|c|c|c|}
\hline Month & 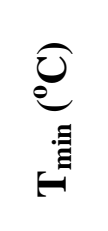 & $\underbrace{0}$ & 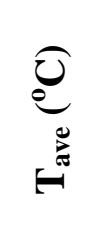 & $\underbrace{a}_{a}$ & 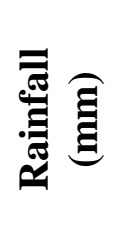 & 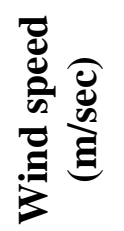 & 竭 \\
\hline Jan. & 6.6 & 12.4 & 9.5 & 79.3 & 120.5 & 1.05 & 6 \\
\hline Feb. & 6.4 & 12.9 & 9.7 & 78.6 & 83.2 & 1.53 & 7 \\
\hline Mar. & 7.5 & 15.4 & 11.5 & 77.7 & 71.7 & 2.3 & 7 \\
\hline Apr. & 10.2 & 19.7 & 15.0 & 75.4 & 21.9 & 3.13 & 8 \\
\hline May & 13.6 & 24.0 & 18.8 & 59.0 & 9 & 3.8 & 10 \\
\hline Jun. & 16.6 & 27.2 & 21.9 & 58.9 & 0 & 4.16 & 12 \\
\hline Jul. & 18.8 & 28.1 & 23.5 & 61.3 & 0 & 4.57 & 12 \\
\hline Aug. & 19 & 28.1 & 23.6 & 62.3 & 0.7 & 4.38 & 12 \\
\hline Sep. & 17.8 & 26.3 & 22.1 & 62.3 & 9.8 & 2.52 & 10 \\
\hline Oct. & 15.3 & 23.4 & 19.4 & 62.4 & 40.3 & 2.35 & 8 \\
\hline Nov. & 11.1 & 18.2 & 14.7 & 63.2 & 71.4 & 1.34 & 7 \\
\hline Dec. & 8 & 14.0 & 11.0 & 64.1 & 120.6 & 0.88 & 6 \\
\hline
\end{tabular}




\section{Experimental design and treatments}

One-hundred forty-four (6 years old) apple trees (Double red delicious) were divided into seven blocks of twenty four trees. Each block had three replicates of eight trees with at least one guard tree between each block. Two irrigation systems, surface (S) and trickle irrigation (D), were assigned to these blocks. Each irrigation system provides the apple trees with three water levels $(100 \%, 75 \%$, and $50 \%$ from apple irrigation water requirements; $E T_{c}$ ), added to traditional treatments (RET) which was irrigated by rainfall $(549.1 \mathrm{~mm})$ as shown in table (2). $\mathrm{RET}_{34.8}$ treatment presents $34.8 \%$ from water irrigation requirement of apple according to water irrigation requirements calculated by PenmanMonteith equation. The entirely random experimental design was based on two factors, irrigation system and water level with three replicates for each.

Table (2): Experimental design and treatments.

\begin{tabular}{ccccc}
\hline $\begin{array}{c}\text { Irrigation } \\
\text { treatment }\end{array}$ & $\begin{array}{c}\text { Irrigation } \\
\text { system }\end{array}$ & Description & $\begin{array}{c}\text { Total water } \\
\text { requirement, mm }\end{array}$ & $\begin{array}{c}\text { Net water } \\
\text { applied, mm }\end{array}$ \\
\hline SET100 & Surface & $100 \% E T_{c}$ restoration & 2188 & 1639 \\
SET75 & Surface & $75 \% E T_{c}$ restoration & 1641 & 1092 \\
SET50 & Surface & $50 \% E T_{c}$ restoration & 1094 & 545 \\
DET100 & Trickle & $100 \% E T_{c}$ restoration & 1580 & 1031 \\
DET75 & Trickle & $75 \% E T_{c}$ restoration & 1185 & 636 \\
DET50 $_{*}$ & Trickle & $50 \% E T_{c}$ restoration & 790 & 241 \\
RET $_{34.8}$ & Rainfall & $34.8 \% E T_{c}$ restoration & 549.1 & 549.1 \\
\hline
\end{tabular}

* Traditional treatment (Total water distributed was computed by

Penman-Monteith equation. FAO, 1998).

The emitters used in the trickle irrigation system were pressure compensated with flow rate of $8 \mathrm{~L} / \mathrm{h}$, the emitters were spaced at $100 \mathrm{~cm}$ with double row polyethylene tubes $(16 \mathrm{~mm}$ in external diameter with 40 $m$ in length).

\subsection{Determination of crop water irrigation requirement}

FAO has facilitated the calculation of crop water requirements and irrigation planning through a series of technical papers (FAO, 1992; $F A O, 1993$; and FAO, 1998). The FAO Penman-Monteith equation was used to calculate the reference evapotranspiration $E T_{o}$. Crop water requirements $\left(E T_{c}\right)$ over the growing season were determined from $E T_{o}$ according to the following equation using crop coefficient $K_{c}$ : 


$$
E T_{c}=K_{c} . E T_{o}
$$

where $E T_{c}$ is the crop water requirement (mm/month), $K_{c}$ is the crop coefficient and $E T_{o}$ is the reference evapotranspiration $(\mathrm{mm} / \mathrm{month})$. Since there was rainfall $(549.1 \mathrm{~mm})$ during the experimental period, net irrigation requirement was taken to be equal to (ET - Rainfall).

\subsection{Yield and mean fruit weight}

Fruit yield per tree was recorded as sum of individual weights of fruit from that tree. Also the mass of apple fruits was determined using a digital balance after harvesting with an accuracy of $0.01 \mathrm{~g}$.

\subsection{Water use efficiency}

Water use efficiency (WUE, $\mathrm{kg} / \mathrm{m}^{3}$ ) was calculated as the ratio between fresh total yield $(\mathrm{kg} / \mathrm{ha})$ and total water used $\left(\mathrm{m}^{3} / \mathrm{ha}\right)$, (Lovelli et al., 2007).

\subsection{Moisture content of apple fruit}

Apple fruits were washed and dried then cut into thin slices. The slices were placed in an oven set to about $105{ }^{\circ} \mathrm{C}$ for 24 hours and slices were weighed again. Moisture content wet basis can be calculated by the equation:

\subsection{Fiber content in apple fruit}

$$
\text { Moisture content }=\frac{\text { Initial weight }- \text { dry weight }}{\text { Initial weight }} \times 100
$$

Apple fiber were obtained by washing, coring, chopping and separation of juice by pressing, then sample were dried at $60{ }^{\circ} \mathrm{C}$ during $30 \mathrm{~min}$. Each treatment was replicated three times.

\subsection{Standard quality parameters measurements}

Changes in apple fruit quality during growth were assessed in the experiment at seven water regimes using 100 fruits per replicate for each treatment. Fruits were randomly sampled from outer and mid-canopy positions.

According to UNECE Standard (2007 and 2011), which concerns the marketing and commercial quality control of apples, the quality parameters measured in this research were fruit diameter, weight, fruit size classification, total soluble solids (TSS), firmness and sugar content. The samples were tested in Faculty of Science - Omar El-Mukhtar University according to (AOAC 1990). 
The firmness of a fruit is linked to the state of maturity and ripeness. The skin was removed using slicers to a $1 \mathrm{~mm}$ cutting depth, and flesh firmness was then measured with a dynamometer equipped with a $8 \mathrm{~mm}$ diameter plunger tip that penetrates the flesh of apple to a depth of 11 $\mathrm{mm}$. The firmness was measured in three positions; up and down apple fruit in the $\mathrm{x}$-axis (length), third position in the minor dimension (width) at right angles to the longitudinal axis (thickness) (Mohsenin, 1986).

Fruit size classification was divided into four diameter categories according to Kücükyumuk et al. (2012); Extra (>75 mm), class 1 (68-75 $\mathrm{mm})$, class $2(60-68 \mathrm{~mm})$, and other $(<60 \mathrm{~mm})$.

\section{RESULTS AND DISCUSSION \\ 1. Apple water irrigation requirements}

The total amounts of irrigation water applied during 2011/2012 season for the irrigation levels treatments in this study were 2188, 1641 and $1094 \mathrm{~mm}$ for $\mathrm{SET}_{100}, \mathrm{SET}_{75}$ and $\mathrm{SET}_{50}$ treatments (in case of surface irrigations), respectively, while 1580, 1185 and $790 \mathrm{~mm}$ for $\mathrm{DET}_{100}$, $\mathrm{DET}_{75}$ and $\mathrm{DET}_{50}$ treatments (in case of trickle irrigations), respectively.

The water requirement was determined for different months by using FAO Penman-Monteith's formula (Allen et al., 1998) based on crop growth stages and climatic data. For treatment $\mathrm{RET}_{34.8}$, the water irrigation applied was $549.1 \mathrm{~mm}$ by rainfall.

\section{Apple tree yield and mean fruit weight}

The average values of fruit mass and apple tree yield are shown in figure (1). It's clear that, for surface irrigation system, the average fruit masses were 134.3, 136.2 and $149.4 \mathrm{~g}$ and the corresponding average gross yields per tree were 51.6, 54.7 and $59.7 \mathrm{~kg}$ for treatments $\mathrm{SET}_{50}, \mathrm{SET}_{75}$ and $\mathrm{SET}_{100}$, respectively. For trickle irrigation system, the average fruit masses were 144.7, 199.7 and $216.3 \mathrm{~g}$ and the corresponding average gross yields per tree were 51.8, 65.0, and $67.9 \mathrm{~kg}$ for treatments $\mathrm{DET}_{50}$, $\mathrm{DET}_{75}$ and $\mathrm{DET}_{100}$, respectively. For traditional treatment $\left(\mathrm{RET}_{34.8}\right)$, the average fruit mass was $121.6 \mathrm{~g}$ and the corresponding average gross yield per tree was $49.3 \mathrm{~kg}$ (figure 1). The results showed that treatments $\mathrm{DET}_{75}$ and $\mathrm{DET}_{100}$ had mean fruit mass greater than other treatments.

\section{Effect of water regimes on water use efficiency}

The average values of apple water use efficiency (WUE) are shown in figure (2). From figure (2), it is clear that the $W U E$ values were higher 
with trickle irrigation treatments when compared to surface irrigation treatments. The maximum WUE $\left(2.62 \mathrm{~kg} / \mathrm{m}^{3}\right)$ treatment was found with $\operatorname{DET}_{50}$ and the minimum WUE $\left(1.00 \mathrm{~kg} / \mathrm{m}^{3}\right)$ treatment was found with $\mathrm{SET}_{100}$. Treatment $\mathrm{RET}_{34.8}$ recorded the maximum value $\left(3.22 \mathrm{~kg} / \mathrm{m}^{3}\right)$ than both surface and trickle irrigation systems. In general WUE increased with decreasing water irrigation on both irrigation systems used in the study.

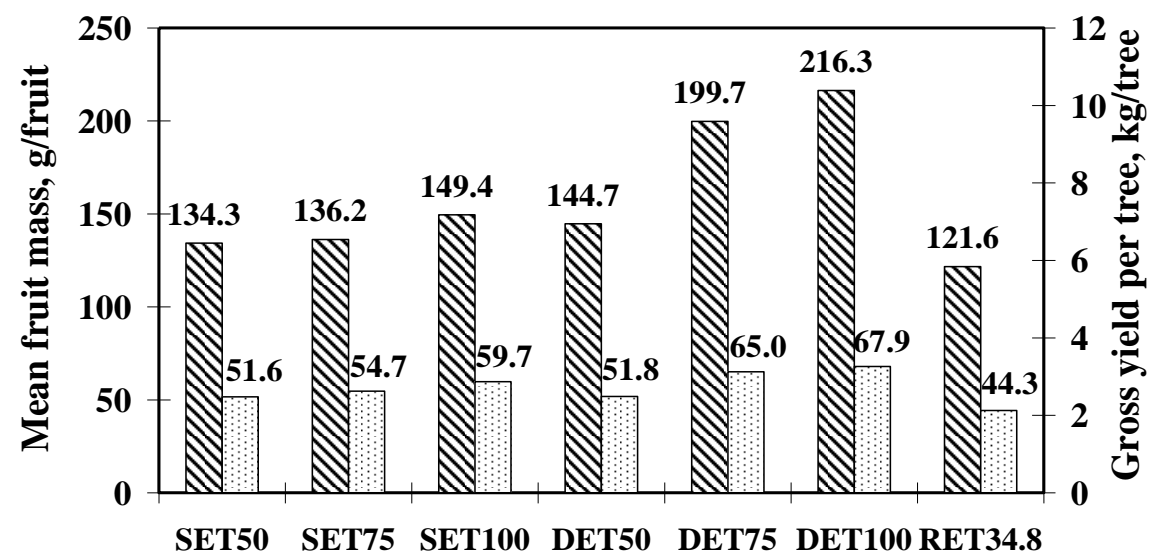

Different water regimes

\$ Mean fruit mass $\quad$ Gross yield per tree

Figure (1): Mean apple fruits mass and tree yield with different water regimes.

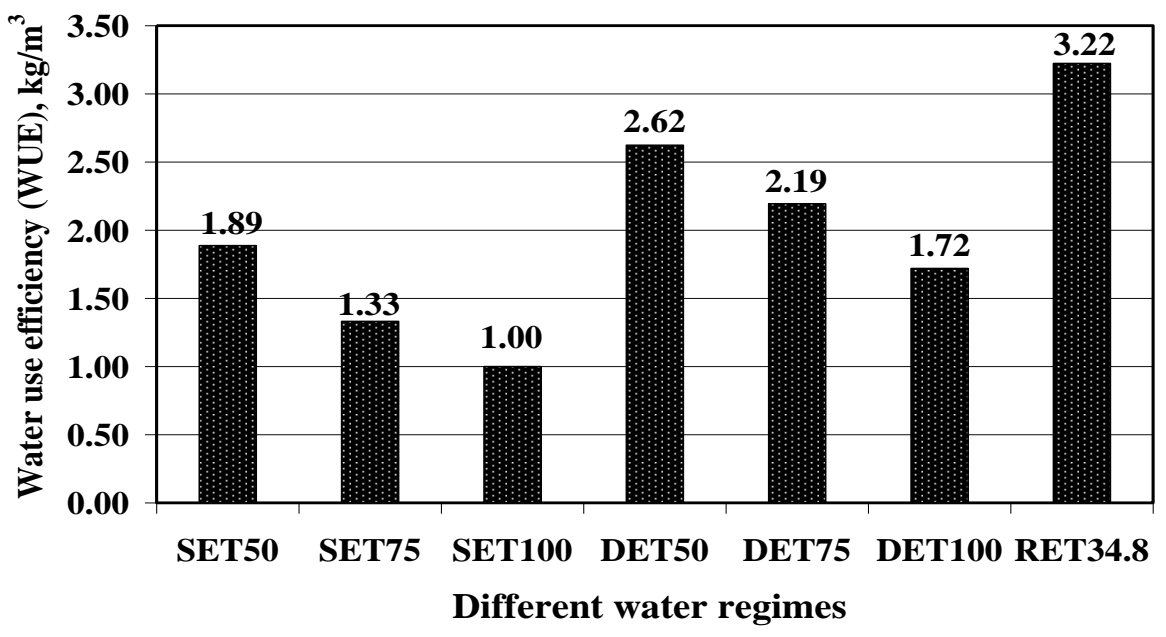

Figure (2): Water use efficiency (WUE) under different water regimes. 


\section{Moisture content of apple fruit}

As shown in figure (3), the total moisture content of apple fruit was increased by increasing water irrigation applied. The maximum value of moisture content in apple fruit was $86.7 \%$ for treatment $\mathrm{DET}_{100}$ and the minimum value was $81.5 \%$ for treatment $\mathrm{SET}_{50}$. For treatment $\mathrm{RET}_{34.8}$, moisture content was $81.4 \%$. The total water content values in fruits was higher with trickle irrigation treatments when compared to surface irrigation treatments (figure 3).

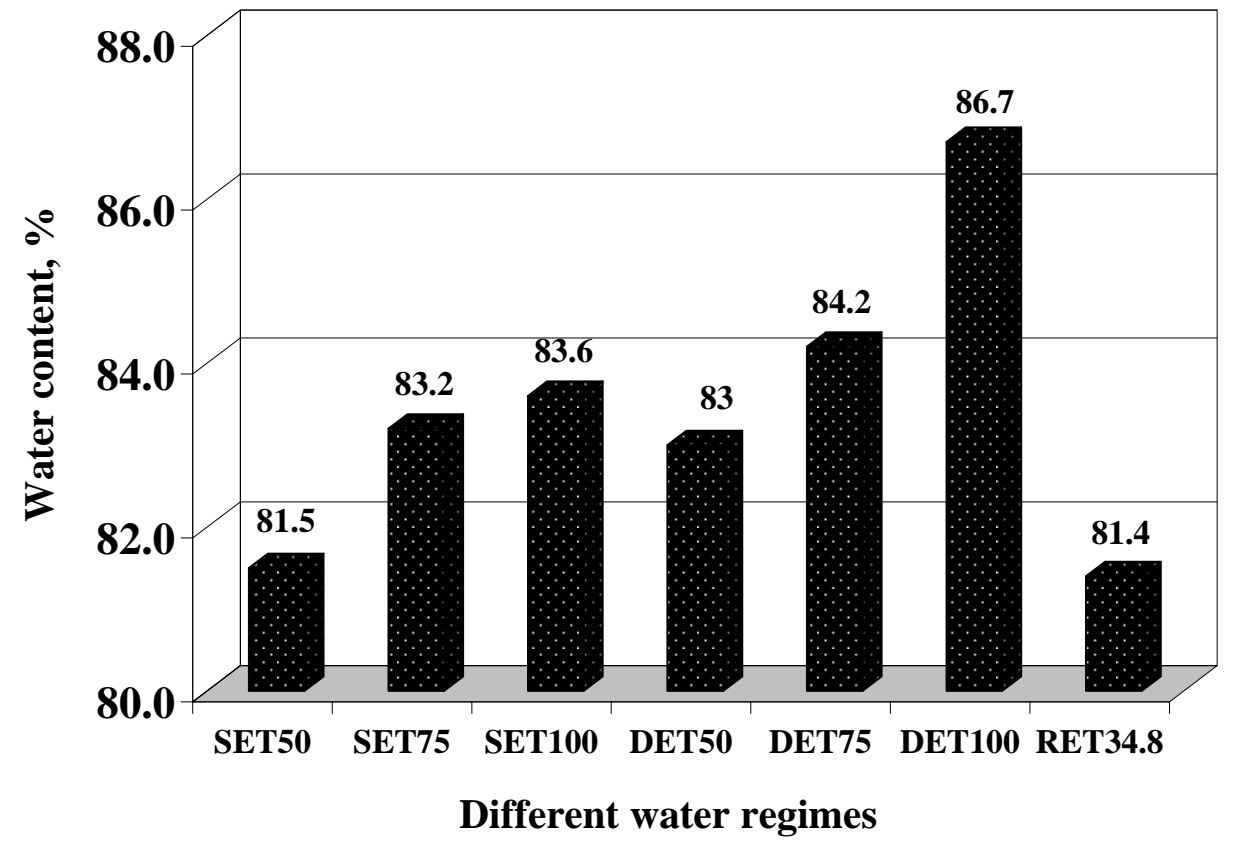

Figure (3): Total water content of apple fruit at different water regimes.

\section{Fiber content of apple fruit}

Results of fiber content measurements are presented in table (3) and figure (4). The results showed that the total fiber content decreased by increasing water irrigation applied. Surface irrigation treatment $\left(\mathrm{SET}_{50}\right)$ showed higher fiber content $(5.8 \%)$ value, while trickle irrigation treatment $\left(\mathrm{DET}_{100}\right)$ showed lower fiber content $(3.8 \%)$ value (table 3$)$. For traditional treatment $\mathrm{RET}_{34.8}$, fiber content was $6.2 \%$. The total fiber content values in fruits were higher with surface irrigation treatments when compared to trickle irrigation treatments (figure 4). 
According to the productivity of apple fruits per irrigation, the total fiber content differed. Thus the maximum value was 0.503 ton/fed for $\mathrm{SET}_{50}$, while the minimum value was 0.358 ton/fed for $\mathrm{SET}_{100}$ (figure 4).

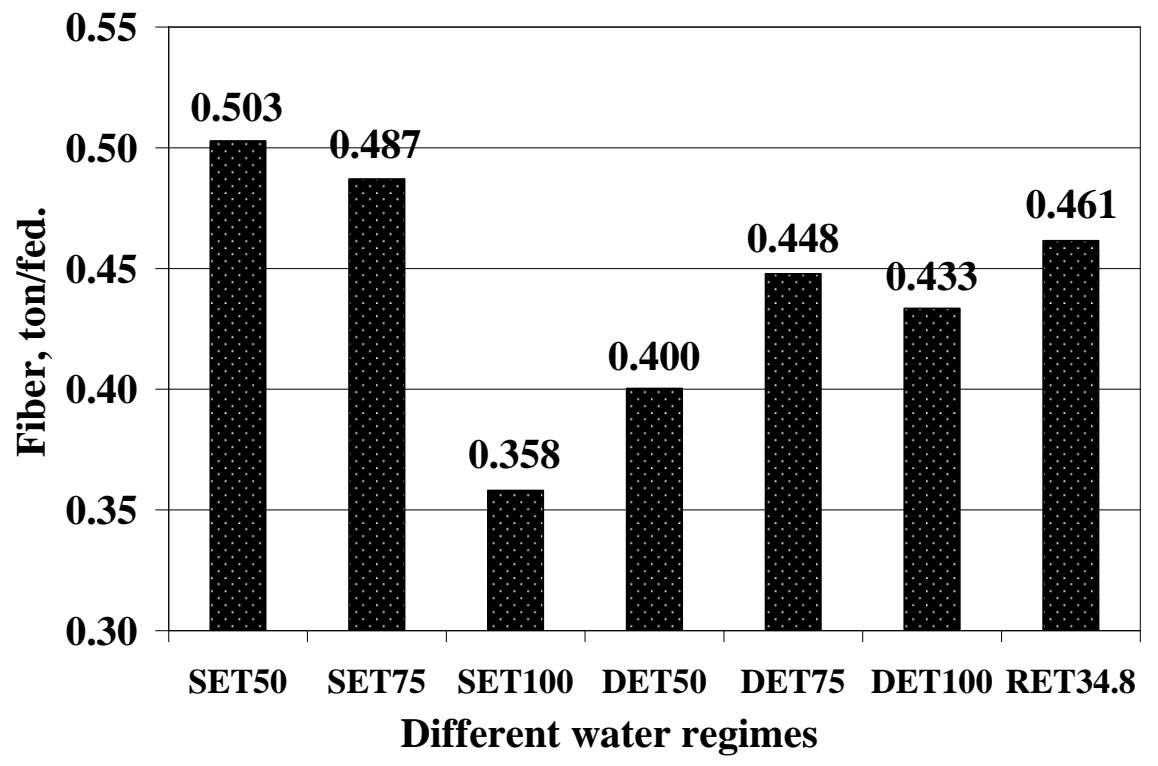

Figure (4): Total productivity of fiber of apple fruits at different water regimes.

Table (3): Effect of different water regimes on TSS, flesh firmness, sugar, fiber, moisture content, average gross yield per tree and yield of the apple fruit.

\begin{tabular}{|c|c|c|c|c|c|c|c|}
\hline \multirow{2}{*}{ Attributes } & \multicolumn{7}{|c|}{ Water regimes } \\
\hline & SET $_{50}$ & SET $_{75}$ & SET $_{100}$ & DET $_{50}$ & $\overline{D E T}_{75}$ & DET $_{100}$ & RET $_{34.8}$ \\
\hline TSS, $\%$ & 15.7 & 13.9 & 13.5 & 15.8 & 13.8 & 13.6 & 16.3 \\
\hline Firmness, $\mathrm{kg} / \mathrm{cm}^{2}$ & 7.86 & 6.26 & 6.18 & 6.93 & 6.11 & 6.10 & 8.05 \\
\hline Sugar, \% & 14.5 & 13.5 & 13.4 & 12.7 & 12.5 & 12.1 & 15.3 \\
\hline Fiber, \% & 5.8 & 5.3 & 3.9 & 4.6 & 4.1 & 3.8 & 6.2 \\
\hline Moisture content, \% & 81.5 & 83.2 & 83.6 & 83.0 & 84.2 & 86.7 & 81.4 \\
\hline Gross yield per tree, $\mathrm{kg} /$ tree & 51.6 & 54.6 & 54.7 & 51.8 & 65.0 & 67.9 & 44.3 \\
\hline Yield, ton/fed. & 8.67 & 9.17 & 9.19 & 8.70 & 10.92 & 11.41 & 7.44 \\
\hline
\end{tabular}

\section{Fruit quality responses to different water regimes}

\subsection{Fruit height, thickness, diameter (width), mass and volume}

The maximum fruit height, thickness, diameter, mass and volume values were obtained from $\mathrm{DET}_{100}$ treatment. $\mathrm{SET}_{75}$ treatment showed the lowest fruit thickness, width, mass and volume values, while the fruit 
height value was the lowest in $\mathrm{DET}_{50}$ treatment. It was identified that fruit height, thickness, width, mass and volume values were increased with increasing amounts of irrigation water in surface and trickle irrigation treatments (Table 4). In all cases $\mathrm{RET}_{34.8}$ treatment showed the lowest values whether trickle or surface irrigation.

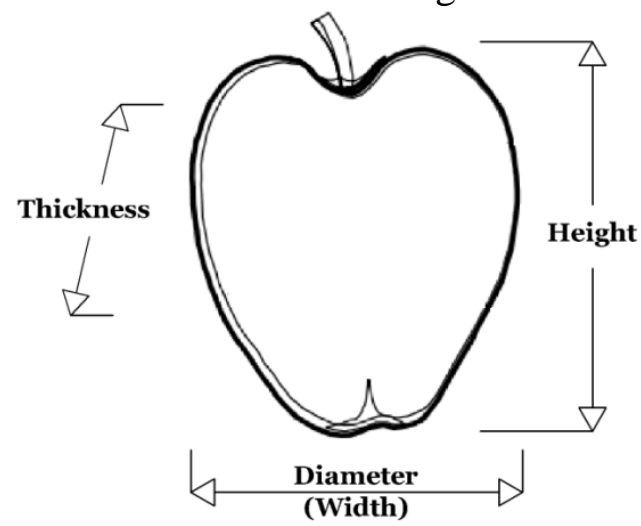

Figure (5): Fruit dimensions (height, diameter and thickness).

Table (4): Fruit height, diameter, thickness, mass and volume for different water regimes.

\begin{tabular}{|c|c|c|c|c|c|c|c|}
\hline items & SET $_{50}$ & SET $_{75}$ & $\mathbf{S E T}_{100}$ & $\mathrm{DET}_{50}$ & $\mathbf{D E T}_{75}$ & DET $_{100}$ & $\mathbf{R E T}_{34.8}$ \\
\hline Height, & 626 & 64.6 & 65.3 & 62.4 & 68.2 & 74.0 & 60.0 \\
\hline Diam & 67.7 & 69.2 & 70.7 & 71.0 & 76.0 & 80.9 & 64.3 \\
\hline Thickness, mm & 64.4 & 67.7 & 70.3 & 67.7 & 72.6 & 77.5 & 60.9 \\
\hline Fruit mass, g & 134.3 & 136.2 & 149.4 & 144.7 & 193.3 & 216.3 & 121.6 \\
\hline Volume, $\mathrm{cm}^{3}$ & 154.7 & 171.2 & 185.8 & 167.7 & 210.9 & 254.0 & 136.5 \\
\hline
\end{tabular}

\subsection{Fruit size classification}

According to fruit size classification, the extra and class 1 fruit ratio increased as the applied water irrigation increased for both irrigation systems, but class 2 fruit ratio decreased after $\mathrm{SET}_{75}$ for surface irrigation (table 6). The highest extra and class 1 fruit ratios were obtained with $\mathrm{DET}_{100}$ treatment for trickle irrigation, while $\mathrm{RET}_{34.8}$ treatment showed the lowest values. The highest ratio of class 2 fruits was noted with surface irrigation treatment $\mathrm{SET}_{100}$.

The highest extra and class 1 fruit ratios were found with trickle irrigation treatments during the study. Surface irrigation treatment showed the lowest values. It has been identified that transition from surface irrigation method to trickle irrigation increased the fruit size, 
which is an important marketing criterion for apple growing. The highest fruit size was obtained with $\mathrm{DET}_{100}$ treatment is used.

Table (5): Fruit size classification under different water regimes, $(\%)$.

\begin{tabular}{|c|c|c|c|c|}
\hline Treatments & Extra & Class 1 & Class 2 & Other \\
\hline SET $_{\mathbf{5 0}}$ & 4.5 & 9.1 & 50 & 36.4 \\
\hline SET $_{\mathbf{7 5}}$ & 6.8 & 18.2 & 56.8 & 18.2 \\
\hline SET $_{\mathbf{1 0 0}}$ & 11.4 & 9.3 & 61.1 & 18.2 \\
\hline DET $_{\mathbf{5 0}}$ & 5.5 & 18.2 & 40 & 36.3 \\
\hline DET $_{\mathbf{7 5}}$ & 20 & 34.5 & 45.5 & 0 \\
\hline DET $_{\mathbf{1 0 0}}$ & 36.2 & 36.5 & 27.3 & 0 \\
\hline RET $_{\mathbf{3 4 . 8}}$ & 0.9 & 8.2 & 36.4 & 54.5 \\
\hline
\end{tabular}

Extra $(>75 \mathrm{~mm})$, class $1(68-75 \mathrm{~mm})$, class $2(60-68 \mathrm{~mm})$, other $(<60$ $\mathrm{mm})$. According to Kücükyumuk et al (2012).

\subsection{Firmness of apple fruit}

Flesh firmness values decreased as the amount of water irrigation increased with both trickle and surface irrigation treatments during the study as shown in figure (6). For surface irrigation treatments, the values of apple fruit firmness were higher when compared to trickle irrigation treatments. The firmnesses were 78.6, 62.6 and $61.8 \mathrm{~N} / \mathrm{cm}^{2}$ for treatments $\mathrm{SET}_{50}, \mathrm{SET}_{75}$, and $\mathrm{SET}_{100}$, respectively in case of surface irrigation and were $69.3,61.1$ and $61.0 \mathrm{~N} / \mathrm{cm}^{2}$ for treatments $\mathrm{DET}_{50}, \mathrm{DET}_{75}$, and $\mathrm{DET}_{100}$, respectively in case of trickle irrigation. In accordance with these results, Drake et al. (1988), Albanese et al. (2007) and Roth et al. (2007), reported that firmness was reduced with decreased water content in fruit. The highest value was found in $\operatorname{RET}_{34.8}\left(80.5 \mathrm{~N} / \mathrm{cm}^{2}\right)$ treatment of traditional irrigation comparing with trickle and surface irrigation. $\mathrm{DET}_{100}$ treatment represented the lowest flesh firmness $\left(61 \mathrm{~N} / \mathrm{cm}^{2}\right)$. An inverse relationship was identified between flesh firmness and applied water irrigation. On the other hand, flesh firmness decreased as fruit length, diameter (width), thickness, mass and volume increased (tables 3 and 4). There were significant polynomial relationships for firmness, diameter and both irrigation systems (figure 6).

\subsection{Total soluble solids (TSS)}

Results of TSS measurements are presented in table (3) and figure (7). For surface irrigation system, TSS was 15.7, 13.9 and $13.5 \%$ for treatments $\mathrm{SET}_{50}, \mathrm{SET}_{75}$ and $\mathrm{SET}_{100}$, respectively and the corresponding total TSS productivity was $1.361,1.277$ and 1.241 ton/fed. For trickle 
irrigation system, TSS was $15.8,13.8$ and $13.6 \%$ for treatments DET $_{50}$, $\mathrm{DET}_{75}$ and $\mathrm{DET}_{100}$, respectively and the corresponding total TSS productivity was $1.375,1.507$ and 1.551 ton/fed. Even though RET $_{34.8}$ treatment had the highest TSS (16.3\%), but had the lowest total TSS productivity (1.213 ton/fed).

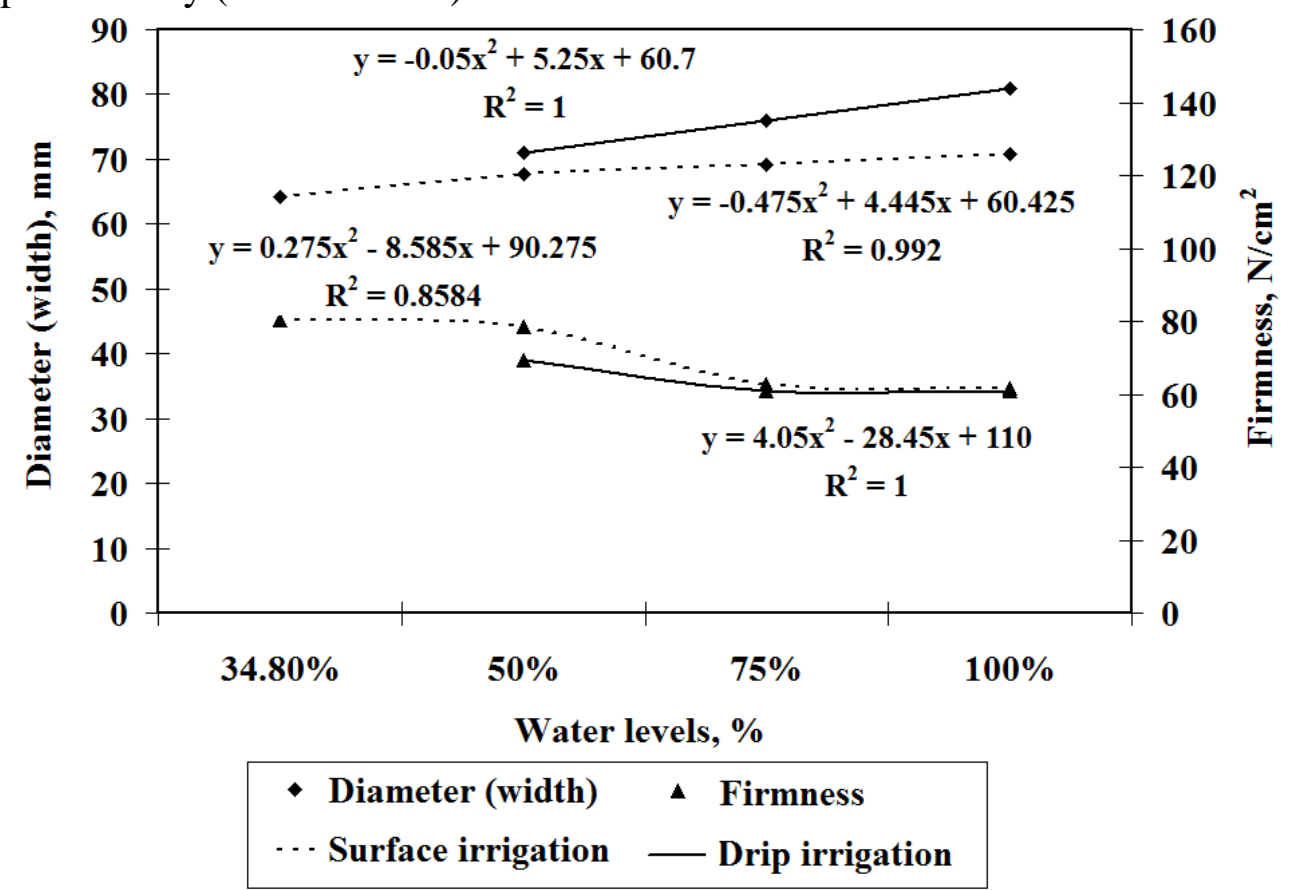

Figure (6): Firmness and diameter of apple fruit at different water regimes.

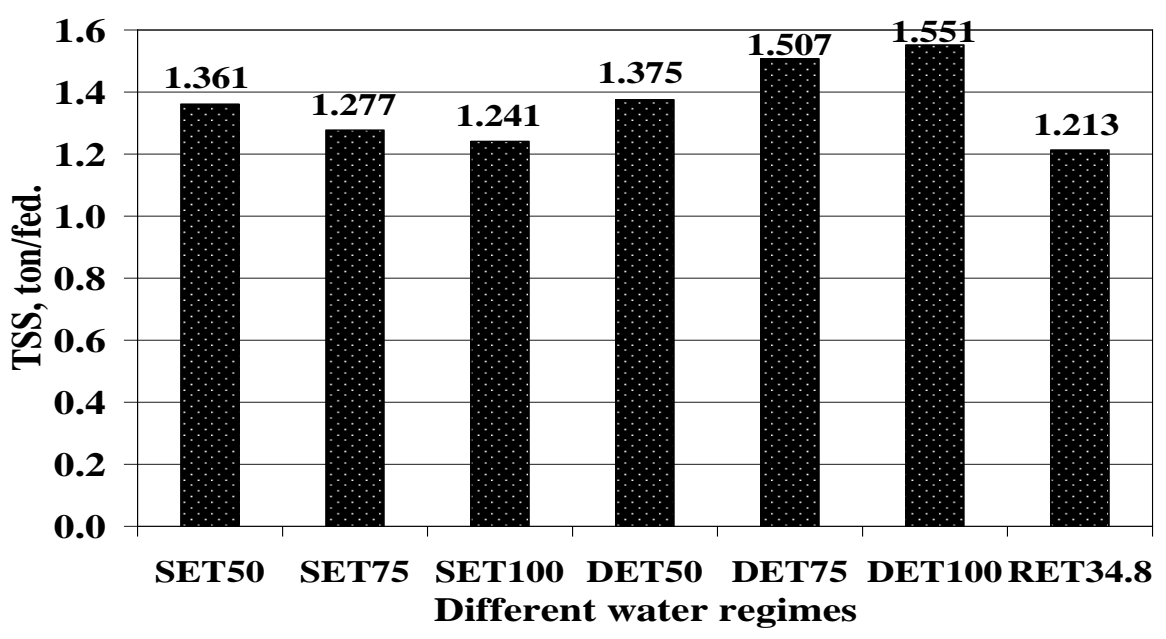

Figure (7): Total productivity of soluble solids of apple fruits at different irrigation regimes. 


\subsection{The fruit sugar content}

Results of sugar content measurements are presented in table (3) and figure (8). For surface irrigation system, sugar content was 14.5, 13.5 and $13.4 \%$ for treatments $\mathrm{SET}_{50}, \mathrm{SET}_{75}$ and $\mathrm{SET}_{100}$, respectively and the corresponding total sugar productivity was 1.257, 1.238 and 1.231 ton/fed. For trickle irrigation system, sugars content was 12.7, 12.5 and $12.1 \%$ for treatments $\mathrm{DET}_{50}, \mathrm{DET}_{75}$ and $\mathrm{DET}_{100}$, respectively and the corresponding total sugar productivity was 1.105, 1.365 and 1.380 ton/fed. For RET $_{34.8}$ treatment, the sugar content was $15.3 \%$ and the corresponding total productivity of sugars was 1.139 ton/fed.

The results showed that the total sugar and TSS productivities decreased with increasing water irrigation in surface irrigation, while the total sugar and TSS productivities increased with increasing water irrigation in trickle irrigation. This is due to insignificant differences in production in relation to treatments of surface irrigation compared to trickle irrigation treatments.

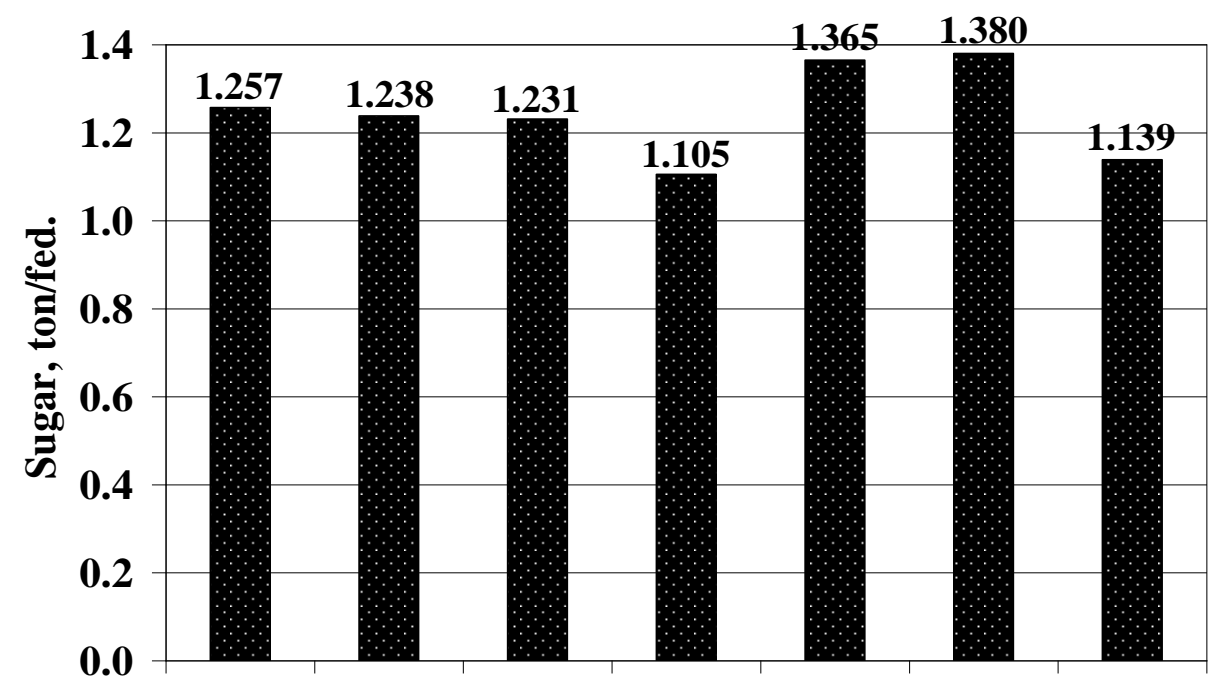

SET50 SET75 SET100 DET50 DET75 DET100RET34.8 Different water regimes

Figure (8): Total productivity of sugars content of apple fruits at different irrigation regimes. 


\section{CONCLUSION}

Experiment was done during the 2011/2012 growing season in a commercial apple (double red delicious) orchard (spacing $5 \times 5 \mathrm{~m}$ ) in Raaseltorab - El-Bayda (Libya) to investigate the effect of surface and trickle irrigation systems on yield and quality of apple fruits under three water levels $\left(100 \% E T_{c}, 75 \%\right.$ and $\left.50 \%\right)$. The water requirement $(100 \%$ $E T_{c}$ ) was calculated by FAO Penman-Monteith equation according to climatic conditions of the area (1946 to 2011). The quality parameters that were investigated are fruit height, thickness, diameter (width), mass, volume, fruit size classification, firmness, TSS and sugar according to UNECE Standard (2007 and 2011).

\section{The results showed that:}

1. Calculated water irrigation requirements by FAO Penman-Monteith equation was $1580 \mathrm{~mm} / \mathrm{season}$, which present $\left(100 \% E T_{c}\right)$ the treatments $\mathrm{SET}_{100}$ and $\mathrm{DET}_{100}$.

2. The gross yields per tree and mean fruit weights increased by increasing applied irrigation water for both surface and trickle irrigations. The maximum gross yield per tree and fruit masses were $67.9 \mathrm{~kg}$ and $216.3 \mathrm{~g}$ for the same treatment of $\mathrm{DET}_{100}$, while the minimum values were $49.3 \mathrm{~kg}$ and $121.6 \mathrm{~kg}$ for the same treatment of $\mathrm{RET}_{34.8}$.

3. The water use efficiencies (WUE) decreased by increasing applied irrigation water for both surface and trickle irrigations. The maximum WUE was $3.22 \mathrm{~kg} / \mathrm{m}^{3}$ for treatment $\mathrm{RET}_{34.8}$, while the minimum was $1.38 \mathrm{~kg} / \mathrm{m}^{3}$ for treatment $\mathrm{SET}_{100}$.

4. The moisture content increased by increasing applied irrigation water for both surface and trickle irrigations. The maximum moisture content was $86.7 \%$ for treatment DET $_{100}$, while the minimum was $81.4 \%$ for treatment $\mathrm{SET}_{100}$. 
5. The fiber content decreased by increasing applied irrigation water for both surface and trickle irrigations. The maximum fiber content was $6.2 \%$ for treatment $\mathrm{RET}_{34.8}$ while the minimum was $3.8 \%$ for treatment $\mathrm{DET}_{100}$.

6. The extra and class 1 fruit ratios increased as the applied irrigation water increased for both irrigation systems, but class 1 fruit ratio decreased after $\mathrm{SET}_{75}$ for surface irrigation. The maximum extra and class 1 fruit ratios were obtained with DET $_{100}$ treatment, while $\mathrm{RET}_{34.8}$ treatment indicated the lowest values.

7. The fruit firmness decreased by increasing applied irrigation water for both surface and trickle irrigations. The maximum fruit firmness was $80.5 \mathrm{~N} / \mathrm{cm}^{2}$ for treatment $\mathrm{RET}_{34.8}$, while the minimum was 61 $\mathrm{N} / \mathrm{cm}^{2}$ for treatment $\mathrm{DET}_{100}$.

8. The fruit total soluble content (TSS) decreased by increasing applied irrigation water for both surface and trickle irrigations. The maximum TSS was $16.3 \%$ for treatment $\mathrm{RET}_{34.8}$, while the minimum was $13.5 \%$ for treatment $\mathrm{SET}_{100}$.

9. The fruit sugar content decreased by increasing applied irrigation water for both surface and trickle irrigations. The maximum fruit sugar content was $15.3 \%$ for treatment $\mathrm{RET}_{34.8}$, while the minimum was $12.1 \%$ for treatment $\mathrm{DET}_{100}$.

10. The TSS and sugar productivities increased by increasing applied irrigation water for both surface and trickle irrigations. The maximum TSS and sugar productivities were 1.551 and 1.38 ton/fed. for the same treatment $\mathrm{DET}_{100}$ while the minimum values were 1.213 and 1.139 ton/fed. for the same treatment $\mathrm{RET}_{34.8}$.

According to the results of the study, it is suggested that transition from surface irrigation to trickle irrigation method positive effects on yield and fruit quality of apple trees which had previously been irrigated by rainfall for many years. 


\section{REFERENCES}

Albanese, D.; L. Cinquanta, and M. Di Matteo. 2007. Effect of an innovative dipping treatment on the cold storage of minimally processed Annurca apples. Food Chem. 105: 1054-1060.

Allen, R.G.; L.S. Pereira; D. Raes and M. Smith, 1998. Crop evapotranspiration. Guidelines for computing crop water requirements. FAO irrigation and Drainage. Paper No. 56, FAO, Rome, Italy, pp: 300.

AOAC, 1990. Official methods of analysis, 15th ed. Assoc. Official Analytical Chemists, Wash, DC, USA.

Caspari, H. W.; M. H. Behboudian; D. J. Chalmers; B. E. Clothier and F. Lenz. 1996. Fruit characteristics of 'Hosui' Asian pears after deficit irrigation. Hort. Sci. 31:162.

Dabbou, S.; H. Chehab; B. Faten; D. Sihem; S. Esposto; R. Selvaggini; A. Taticchi; M. Servili; G. F. Montedoro and M. Hammami. 2010. Effect of three irrigation regimes on Arbequina olive oil produced under Tunisian growing conditions. Ag. Water Manag. 97, (5): 763-768.

Drake, S.R.; F.E. Larsen; J.K. Fellman and S.S. Higgins. 1988. Maturity, storage quality, carbohydrate, and mineral content of 'Goldspur' apples as influenced by rootstock. J. Am. Soc. Hort. Sci. 113, 6: 949-952.

Endres, L. 2007. Daily and seasonal variation of water relationship in sugar apple (Annona squamosa L.) under different irrigation regimes at semi-arid Brazil. Sci. Hort, 113 (2007) 149-154

English, M. and S. N. Raja. 1996. Perspectives on deficit irrigation. Ag. Water Manag. 32: 1-14.

Fallahi, E.; N. Denise; H. N. Gerry; B. Fallahi and S. Bahman. 2010. Efficient irrigation for optimum fruit quality and yield in apples. Hort. Sci, vol. 45 (11): 1616-1625. 
FAO, 1992. CROPWAT. A computer program for irrigation planning and management. Ir. and Drain. Paper No. 46. Rome.

FAO, 1993. CLIMWAT for CROPWAT. A climatic database for irrigation planning and management. Ir. and Drain. Paper No. 49. Rome.

FAO, 1998. Crop evapotranspiration; guidelines for computing crop water requirements. Ir. and Drain. Paper No. 56. Rome.

Kilili, A. W.; M. H. Behboudian and T. M. Mills. 1996. Composition and quality of 'Braeburn' apple fruit under reduced irrigation. Sci. Hort. 67: 1-11.

Kücükyumuk, C.; E. Kacal; A. Ertek; G. Öztürk and Y. S. Kurttas. 2012. Pomological and vegetative changes during transition from flood irrigation to trickle irrigation: Starkrimson Delicious apple variety. Sci. Hort. 136:17-23.

Lovelli, S.; M. Perniola; A. Ferrara and T. Di Tommaso. 2007. Yield response factor to water (Ky) and water use efficiency of Carthamus tinctorius L. and Solanum melongena L. Ag. Water Manag. 92, 73-80.

Maja, M. C.; S. Franci and V. Robert. 2009. Changes in the inner quality parameters of apple fruit from technological to edible maturity. Acta Agriculturae Slovenica, 93 (1): 17 - 29.

Maria J. B.; P. M. Vossen1; S. R. Grattan; J. H. Connell and V. S. Polito. 2006. Tree irrigation levels for optimum chemical and sensory properties of olive oil. Hort. Sci April 2006 vol. 41 no. 2 427-432.

Mills, T. M., M. H. Behboudian, and B. E. Clothier. 1996. Water relations, growth and the composition of 'Braeburn' apple fruit under deficit irrigation. J. Am. Soc. Hort. Sci. 121:286-291. 
Mohsenin, N. N. 1986. Physical properties of plant and animal materials. Gordon and Breach Sci. Pub, N. Y.

Roth, E.; A. Berna; K. Beullens; S. Yarramraju; J. Lammertyn; A. Schenk and B. Nicolai. 2007. Postharvest quality of integrated and organically produced apple fruit. Postaharvest Biol. Technol. 45: 11-19.

Shock, C.C.; J.C. Zalewski; T.D. Stieber and D.S. Burnett. 1992. Impact of early-season water deficits on Russet Burbank plant development, tuber yield and quality. Am. Potato J. 69: 793-803.

UNECE STANDARD FFV-50 2007. Apples quality standards. United Nations Economy Commission for Europe. 53 rd. Ses. N Y., Geneva, 21-25 May 2007.

UNECE STANDARD FFV-50 2011. Apples. United Nations Economy Commission for Europe. 53 rd. Ses. N. Y., Geneva, 10 November 2011.

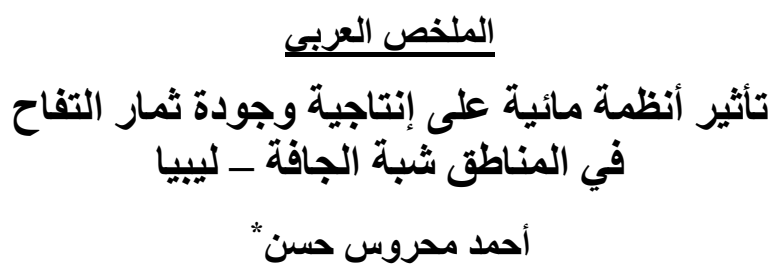

يهدف هذا البحث إلى دراسة تأثير نظامي الري السطحي (S) و الري بالتنقيط (D) على جودة ثمار التفاح صنف Double red delicious تحت ثلاثة مستويات مياه ري مختلفة في المناطق شبة الرطبة وهي ET

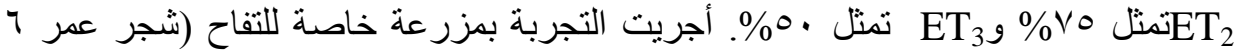

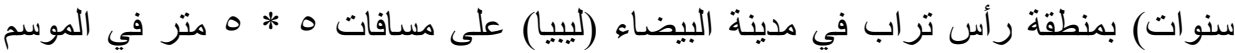

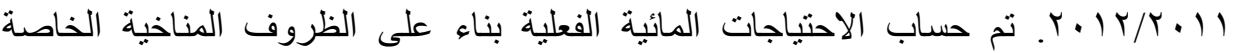

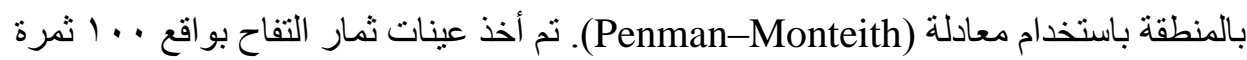
من كل معاملة لإجر اء بعض القياسات وخواص الجودة القياسية طبقا للمواصفات القياسية لـ لـ لـاعل (UNECE 2007 and 2011)

* مدرس بقسم الهندسة الزراعية ـ كلية الزراعة - جامعة القاهرة. 


\section{وقد بينت الاراسة ما يلي:}

ا. كانت الاحتياجات المائية المحسوبة بمعادلة (FAO Penman-Monteith) لشجرة التفاح • •10^ مم/موسم والتي تمثل (100\% ET ET

. $\mathrm{DET}_{100}$

ץ. زيادة متوسط وزن ثمرة التفاح وكذلك إنتاج شجرة التفاح بزيادة كمية المياه المضافة في كلا من نظامي الري السطحي والري بالتنقيط وكانت أقصى كتله لثمار التفاح

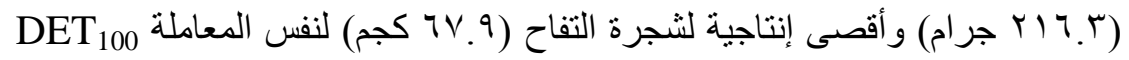

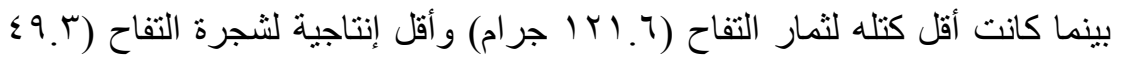
كجم) لنفس المعاملة r. نقت كفاءة الاستخدام المائي بزيادة كمية المياه المضافة في كلا من نظامي الري

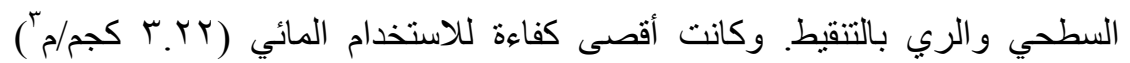

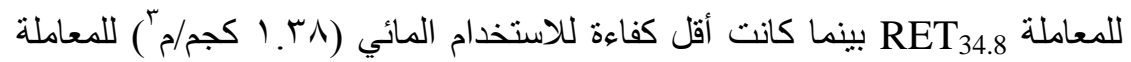

. $\mathrm{SET}_{100}$

ع. ـ زاد المحتوى الرطوبي للثمرة بزيادة كمية المياه المضافة في كلا من نظامي الري

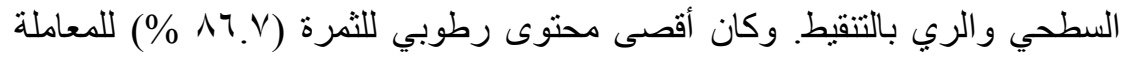

DET 100 ○. نقص محتوى الثمرة من الألياف بزيادة كمية المياه المضافة في كلا من نظامي الري السطحي و الري بالتقفي. وكان أقصى محتوى للألياف للثمرة (r.7 \% \%) للمعاملة

RET RET $_{34.8}$ 7. زيادة التصنيف الحجمي لثمار التفاح بالنسبة إلى الفئة اكستر ا و الفئة ا بزيادة كمية المياه المضافة في كلا من نظامي الري السطحي و الري بالتنقيط. حيث كانت أعلى

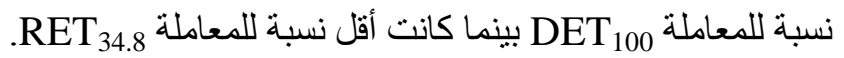
V. نقصت صلادة (Firmness) ثمار التفاح بزيادة كمية المياه المضافة في كلا من

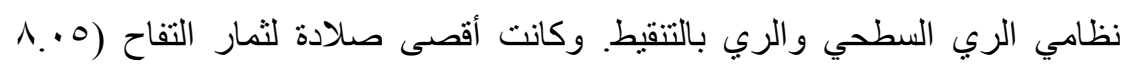

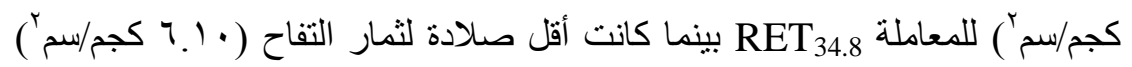

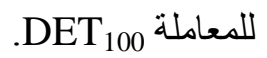
^. نقصت نسبة المواد الصلبة الذائبة (TSS) لثمار التفاح بزيادة كمية المياه المضافة في كلا من نظامي الري السطحي و الري بالتنقيط. وكانت أقصى نسبة للمواد الصلبة 


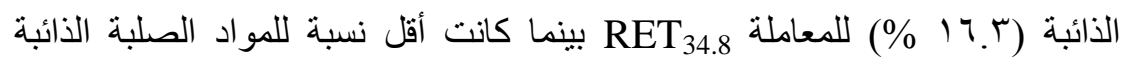

.SET 100 (13.5\%)

9 9. نقصت نسبة السكر لثمار التفاح بزيادة كمية المياه المضافة في كلا من نظامي الري

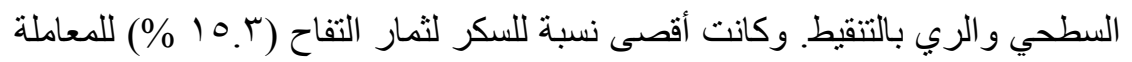

RET 34.8

• (. زيادة إنتاجية كلا من المواد الصلبة الذائبة (TSS) والسكر لثمار التفاح في الفدان

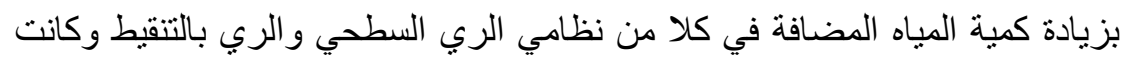

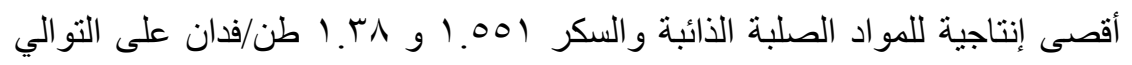
لنفس المعاملة DET

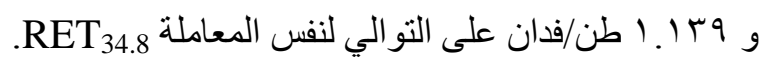

يقتر ح من النتائج السابقة الانتقال من نظام الري المطري أو نظام الري السطحي الى نظام الري

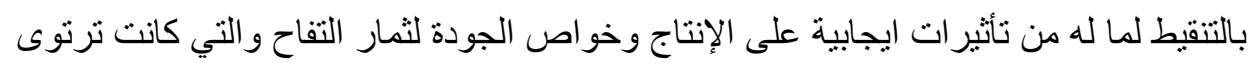
بالأمطار لسنو ات طويلة. 